\title{
Emisje otoakustyczne wywołane trzaskiem u osób palących i niepalących
}

\section{Transient evoked otoacoustic emissions in smoking and nonsmoking persons}

\author{
Magdalena Kozieł ${ }^{1,2,3}$, W. Wiktor Jędrzejczak ${ }^{1}$, Krzysztof Kochanek $^{1}$, Adam Piłka ${ }^{1}$, \\ Karolina Dajos-Krawczyńska ${ }^{1}$, Henryk Skarżyński ${ }^{1}$ \\ ${ }^{1}$ Instytut Fizjologii i Patologii Słuchu, Światowe Centrum Słuchu, Warszawa/Kajetany \\ ${ }^{2}$ Centrum Słuchu i Mowy, Kajetany \\ ${ }^{3}$ Instytut Narządów Zmysłów, Kajetany
}

Adres autora: Magdalena Kozieł, Centrum Słuchu i Mowy, ul. Mokra 7, Kajetany, 05-830 Nadarzyn, e-mail: m.koziel@csim.pl

\section{Streszczenie}

Wstęp: Z uwagi na fakt, że palenie tytoniu może wywoływać efekt ototoksyczny, może tym samym wpływać na rejestrację sygnału emisji otoakustycznych. Niniejsze badania miały na celu określenie, w jaki sposób palenie papierosów wpływa na wyniki emisji otoakustycznych wywołanych trzaskiem (ang. Transient Evoked Otoacoustic Emissions, TEOAE) u młodych osób ze słuchem prawidłowym.

Materiał i metody: Zbadano 20 osób palących, w tym 10 kobiet oraz 10 mężczyzn, oraz 20 osób niepalących, 10 kobiet oraz 10 mężczyzn, w wieku od 19 do 30 lat. Wszystkie osoby badane miały słuch prawidłowy. Ocenie poddano wyniki średniego poziomu odpowiedzi oraz stosunku sygnału do szumu (ang. Signal to Noise Ratio, SNR) TEOAE dla poszczególnych częstotliwości $(1 ; 1,4 ; 2 ; 2,8 ; 4 \mathrm{kHz})$ w badanych grupach.

\begin{abstract}
Wyniki: Analiza uzyskanych wyników wykazała, że dla żadnej z rozpatrywanych częstotliwości nie ma istotnych statystycznie różnic, dla poziomu istotności $(\mathrm{p}<0,05)$, pomiędzy średnim poziomem TEOAE $\mathrm{w}$ uchu prawym i lewym pomiędzy grupą osób palących i niepalących. Osoby palące uzyskiwały niższe poziomy odpowiedzi TEOAE dla częstotliwości 1,4;2,8 i $4 \mathrm{kHz}$ w uchu prawym oraz dla $1 ; 1,4 ; 2 ; 2,8 \mathrm{kHz}$ w uchu lewym, jednak różnice te nie były istotne statystycznie. W przypadku SNR w uchu prawym różnice wystąpiły dla częstotliwości 2,8 oraz $4 \mathrm{kHz}$, natomiast w uchu lewym dla częstotliwości 1; 1,4;2 oraz 2,8 kHz. Dla tych częstotliwości w grupie osób palących obserwowano niższe wartości SNR, jednak podobnie jak w przypadku poziomu odpowiedzi TEOAE różnice nie były istotne statystycznie.
\end{abstract}

Wnioski: Palenie papierosów wydaje się nie mieć istotnego wpływu na badane parametry TEOAE w przypadku osób palących stosunkowo krótko, $\mathrm{z}$ prawidłowym słuchem.

Słowa kluczowe: palenie tytoniu • emisje otoakustyczne wywołane trzaskiem (TEOAE) • poziom sygnału • stosunek sygnału do szumu (SNR)

\section{Abstract}

Introduction: Due to the fact that smoking can have the ototoxic effect, it may therefore affect registration of otoacoustic emission signal. The main aim of the present study was to assess how cigarette smoking influences transient-evoked otoacoustic emissions (TEOAEs) in young people with normal hearing.

Material and methods: The studied group consisted of 20 smoking people, 10 women and 10 men, and 20 nonsmoking people, 10 women and 10 men aged 19-30 years. All subjects had normal hearing. Average response level and signal to noise ratio (SNR) of TEOAEs were assessed at selected frequencies $(1,1.4,2,2.8,4 \mathrm{kHz})$ in the studied groups.

Results: Data analysis has shown that there were no significant statistical differences, for the level of significance $(\mathrm{p}<0.05)$, between mean TEOAE response level in right and left ear in smoking and non-smoking groups at any of tested frequencies. For smoking people TEOAE response levels were lower than for non-smoking people at frequencies 1.4, 2.8 and $4 \mathrm{kHz}$ in the right 
ear and at frequencies $1,1.4,2,2.8 \mathrm{kHz}$ in the left ear, but those differences were not statistically significant. In case of SNRs, differences were observed at frequencies 2.8 , and $4 \mathrm{kHz}$ in the right ear and at frequencies of $1,1.4,2$, and $2.8 \mathrm{kHz}$ in the left ear. At these frequencies lower SNRs were observed in the smoking group, but similarly to TEOAE response levels, these differences were not statistically significant.

Conclusions: Cigarette smoking seems to have no significant effect on the evaluated parameters of TEOAE in case smokers with normal hearing who have smoked for a relatively short time.

Key words: cigarette smoking • transient evoked otoacoustic emissions (TEOAE) • response level • signal to noise ratio (SNR)

\section{Wstęp}

Papierosy są jedną z używek najbardziej rozpowszechnionych w populacji światowej. Szacuje się, że ponad 1 miliard ludzi jest uzależnionych od tytoniu, $\mathrm{z}$ czego ponad $80 \%$ żyje w krajach nisko i średnio rozwiniętych [1].

Jak wynika $z$ danych epidemiologicznych, coraz więcej młodych ludzi sięga po wyroby tytoniowe. Wyniki badań pokazują, że 1 na 5 osób rasy białej w wieku od 12 do 17 lat pali papierosy, natomiast w przedziale wiekowym 18-25 lat odpowiednio 1 na 10 osób jest uzależniona od tytoniu [2].

Palenie papierosów wpływa w sposób wieloaspektowy na organizm człowieka. Szczególnie widoczne zmiany wywołuje w układzie krążenia oraz układzie immunologicznym. Jak piszą w swojej pracy Ambrose i Barua [3], palenie papierosów powoduje dysfunkcje naczynioruchowe, wywołuje odpowiedź zapalną w organizmie oraz modyfikuje profil lipidowy. Dysfunkcje naczynioruchowe u osób palących są związane między innymi z mniejszą dostępnością tlenku azotu odpowiedzialnego za rozszerzanie naczyń krwionośnych. U osób palących stwierdza się również wzrost wielu markerów reakcji zapalnej, takich jak: białko C-reaktywne, interleukina 6, czynnik martwicy nowotworów. Zmiany te są obecne w organizmach zarówno kobiet, jak i mężczyzn. Osoby palące mają również znacznie podwyższony poziom frakcji LDL cholesterolu oraz trójglicerydów, natomiast frakcja HDL jest u nich obniżona. Dodatkowo stwierdza się, że palenie papierosów sprzyja powstawaniu zakrzepów poprzez wzrost poziomu fibrynogenu.

Dym tytoniowy zawiera ponad 3500 substancji chemicznych oraz 60 substancji kancerogennych. Wśród głównych składników dymu tytoniowego są między innymi metale ciężkie, takie jak: kadm, ołów, chrom, nikiel, rtęć oraz arszenik [4]. Metale ciężkie mogą wywoływać efekt ototoksyczny. Rtęć i arszenik powodują zniszczenie komórek słuchowych, natomiast ołów może powodować dymetylację nerwów w drodze słuchowej [5].

Innym składnikiem dymu tytoniowego jest tlenek węgla. $\mathrm{W}$ porównaniu $\mathrm{z}$ tlenem ma on około 200 razy większe powinowactwo do hemoglobiny, łącząc się z nią tworzy karboksyhemoglobinę, która ma mniejszą zdolność przenoszenia tlenu i może wywoływać hipoksję [6]. Tlenek węgla, redukując dostarczanie tlenu do tkanek, powoduje wystąpienie stresu oksydacyjnego prowadzącego do nadprodukcji niestabilnego, reaktywnego tlenu. Tlen ten może prowadzić do uszkodzenia komórek słuchowych. Na skutek toksycznego działania tlenku węgla dochodzi do nadmiernego uwalniania glutaminy w synapsach znajdujących się poniżej komórek słuchowych. Ostre zatrucie tlenkiem węgla prowadzi do zmysłowo-nerwowej utraty słuchu, która może być odwracalna w sposób częściowy lub całkowity [7].

Niedotlenienie powoduje natychmiastowe obniżenie ciśnienia tlenu w schodach środkowych ślimaka, co współwystępuje ze spadkiem wewnątrzślimakowego potencjału i mikrofoników ślimaka [8].

Emisje otoakustyczne [9] są dźwiękami, które rejestruje się w kanale słuchowym, gdy błona bębenkowa otrzymuje wibracje transmitowane zwrotnie ze ślimaka przez ucho środkowe. Wibracje te powstają jako produkt uboczny unikalnego i wrażliwego mechanizmu znanego jako wzmacniacz ślimakowy. Związane sa one $\mathrm{z}$ prawidłowym funkcjonowaniem komórek słuchowych zewnętrznych [10,11]. $\mathrm{Z}$ uwagi na to, że emisje otoakustyczne są bardzo czułe na wszelkiego rodzaju zaburzenia metaboliczne zachodzące w ślimaku [12], badanie to stanowi bardzo dobre narzędzie do monitorowania ototoksyczności leków czy związków chemicznych, takich jak rozpuszczalniki, metale ciężkie, pestycydy $\mathrm{i}$ inne [13].

W literaturze światowej istnieje wiele doniesień na temat ujemnego wpływu palenia papierosów na narząd słuchu. Można tu przytoczyć między innymi badania prowadzone przez Fabry i wsp. [14], Cruickhanks i wsp. [15], Sharabi i wsp. [16] oraz Paschoal i Azevedo [17], Vinay [18], Korresa i wsp. [19], Durante i wsp. [20]. Wyniki tych badań potwierdziły, że istnieje zależność pomiędzy paleniem papierosów a uszkodzeniem słuchu. Na przykład badania Fabrego i wsp. [14], jak również Cruickhanks i wsp. [15], czy też Sharabiego i wsp. [16] pokazały, że palenie papierosów powoduje uszkodzenie słuchu, które było widoczne między innymi w wynikach audiometrii tonalnej, a w przypadku badań Paschoal i Azevedo [17] zarówno w badaniach audiometrycznych, jak i wynikach emisji otoakustycznych. Ujemny wpływ palenia tytoniu na wyniki emisji otoakustycznych u osób ze słuchem prawidłowym, objawiający się między innymi zmniejszeniem się amplitudy rejestrowanego sygnału, wykazał w swojej pracy Vinay [18]. W badaniach Korresa i wsp. [19] zaobserwowano, że całkowity średni poziom TEOAE jest istotnie statystycznie mniejszy w grupie noworodków eksponowanych na działanie dymu tytoniowego $\mathrm{w}$ porównaniu $\mathrm{z}$ grupą kontrolną. Zbliżone wyniki do zaprezentowanych powyżej uzyskali w swojej pracy Durante i wsp. [20]. W tych badaniach odnotowano również, że średni poziom sygnału emisji otoakustycznych wywołanych trzaskiem jest istotnie statystycznie niższy w grupie noworodków, których matki paliły podczas ciąży.

Niniejsze badania miały na celu określenie, czy i w jaki sposób palenie papierosów wpływa na wyniki emisji 
otoakustycznych wywołanych trzaskiem w populacji młodych osób palących.

\section{Materiał i metody}

Badanie emisji otoakustycznych wywołanych trzaskiem przeprowadzono w grupie 40 osób w wieku od 19 do 30 lat. Grupa ta obejmowała 20 osób niepalących, wśród których było 10 kobiet oraz 10 mężczyzn, oraz 20 osób palących, wśród których było również 10 kobiet i 10 mężczyzn. Średnia wieku w grupie niepalących wynosiła 22 lata i 6 miesięcy, natomiast w grupie palących - 22 lata i 10 miesięcy. W obydwu grupach analizie poddano oboje uszu każdego pacjenta (20 uszu prawych i 20 uszu lewych w każdej grupie).

Przed wykonaniem badań audiologicznych uczestnicy wyrazili na nie pisemną zgodę. Ponadto został przeprowadzony z nimi wywiad, który miał na celu wykluczenie z badań osób z zaburzeniami narządu słuchu, co mogłoby wpłynąć na uzyskane wyniki. Pytania zadane uczestnikom badań dotyczyły między innymi: własnej oceny stanu słuchu, występowania obecnie i w przeszłości problemów ze słuchem, występowania schorzeń otolaryngologicznych, przebytych operacji uszu, chorób przewlekłych, przyjmowania leków ototoksycznych obecnie i w przeszłości, przyjmowania leków hormonalnych przez kobiety, narażenia na działanie hałasu. Pytano również o to, czy dana osoba pali papierosy czy też nie, jak również czy jest narażona w sposób bierny na działanie dymu tytoniowego. Osoby, które zgłosiły, że są narażone w sposób bierny na działanie dymu tytoniowego, zostały wyłączone $\mathrm{z}$ uczestnictwa $\mathrm{w}$ badaniu. W przypadku osób palących pytano o liczbę wypalanych papierosów oraz czas, przez jaki dana osoba pali. Uzyskane odpowiedzi pozwoliły na określenie średniej liczby wypalanych dziennie papierosów, która wynosiła ok. 9,5 papierosa, oraz czasu palenia, który wynosił około 3 lata i 10 miesięcy $(\mathrm{SD}=1,75)$. Jeżeli po wywiadzie z uczestnikiem badania nie stwierdzono obecności czynników mogących wpływać na uzyskane wyniki emisji otoakustycznych, przeprowadzano ocenę audiologiczną.

W ramach tej oceny u każdego uczestnika wykonano audiometrię impedancyjną obejmującą tympanometrię oraz rejestrację ipsilateralnych odruchów $\mathrm{z}$ mięśnia strzemiączkowego. Badanie przeprowadzono za pomoca mostka tympanometrycznego AZ 26 firmy Interacoustic. Warunkiem wykonania kolejnych pomiarów u danego pacjenta było uzyskanie tympanogramu typu „A” oraz prawidłowych progów odruchu z mięśnia strzemiączkowego. Następnie u każdej osoby wykonywano badanie audiometrii tonalnej w zakresie częstotliwości od 125 do $8000 \mathrm{~Hz}$ za pomocą audiometru firmy SD 50 firmy SIEMENS wyposażonego w słuchawki wokółuszne HD 200 firmy Sennheiser. Do dalszych badań zakwalifikowano osoby, u których próg słyszenia wyznaczony na drodze powietrznej na żadnej z badanych częstotliwości nie przekraczał $25 \mathrm{~dB}$ HL.

Badania emisji otoakustycznych - TEOAE wykonano za pomoca urządzenia ILO 292 firmy Otodynamics. W badaniach stosowano trzask nieliniowy o natężeniu ok. $80 \mathrm{~dB}$ SPL. Liczba uśrednień odpowiedzi wynosiła 260.

W przypadku badania TEOAE analizie statystycznej poddano poziom odpowiedzi oraz stosunek sygnału do szumu.
Podczas analizy danych uwzględniano także badane ucho oraz status osoby - palący/niepalący. Do analizy włączano jedynie wyniki, dla których SNR - wyznaczony dla $3 \mathrm{z} 5$ pasm w zakresie częstotliwości $1-4 \mathrm{kHz}$ - był większy niż $3 \mathrm{~dB}$.

Do analizy statystycznej uzyskanych wyników TEOAE wykorzystano test t-Studenta dla prób niezależnych. Za istotne statystycznie przyjmowano wyniki dla poziomu istotności $\mathrm{p}<0,05$.

\section{Wyniki}

\section{Audiometria tonalna}

Analiza za pomocą testu t-Studenta dla prób niezależnych średnich progów słyszenia pomiędzy grupą osób palących i niepalących, osobno dla ucha prawego i lewego, nie wykazała istotnych statystycznie różnic pomiędzy badanymi grupami. Uzyskane wyniki przedstawiono na rycinie 1 i 2.

\section{Różnice w średnich poziomach odpowiedzi} TEOAE w grupie osób palących i niepalących

W dalszej kolejności analizowano średnie wyniki poziomów odpowiedzi TEOAE pomiędzy grupą osób palących i niepalących dla ucha prawego i lewego w zakresie częstotliwości od 1 do $4 \mathrm{kHz}$ (rycina 3). Analiza uzyskanych wyników wykazała, że nie ma istotnych statystycznie różnic pomiędzy średnimi poziomami TEOAE w grupie osób palących i niepalących. Chociaż na pewnych częstotliwościach można zaobserwować niższą amplitudę odpowiedzi w grupie osób palących w porównaniu z niepalącymi. Największe tego typu różnice pomiędzy badanymi grupami wystąpiły w uchu prawym dla częstotliwości $1,4 \mathrm{kHz}$, natomiast w uchu lewym odpowiednio dla częstotliwości 1,4; 2 oraz 2,8 kHz. Jak już wcześniej wspomniano, nie były to jednak różnice istotne statystycznie.

\section{Poziomy SNR}

Również w przypadku poziomów SNR nie zaobserwowano istotnych statystycznie różnic pomiędzy grupą osób palących i niepalących. W przypadku poziomu SNR w uchu prawym największe różnice wystapiły dla częstotliwości 1 oraz $2 \mathrm{kHz}$, ale poziom był większy u osób palących (rycina 4). Natomiast w uchu lewym największe różnice wystąpiły dla częstotliwości 1; 1,4; 2 oraz 2,8 kHz. Na tych częstotliwościach w grupie osób palących obserwowano niższe poziomy SNR.

\section{Dyskusja}

Wyniki niniejszych badań pokazują, iż w grupie młodych osób palących średnie poziomy odpowiedzi TEOAE dla wszystkich badanych częstotliwości nie różnią się od grupy osób niepalących, a obserwowane dla pewnych częstotliwości gorsze wyniki u osób palących nie są istotne statystycznie. Jest to $\mathrm{w}$ pewien sposób niezgodne $\mathrm{z}$ większością doniesień na ten temat w literaturze światowej. Wcześniejsze badania dotyczące TEOAE prowadzone zarówno wśród dorosłych, jak i noworodków wskazują na negatywny wpływ działania dymu tytoniowego na poziom sygnału emisji otoakustycznych. Zarówno z badań prowadzonych przez Vinaya [18], jak i Paschoal i Azevedo [17] 

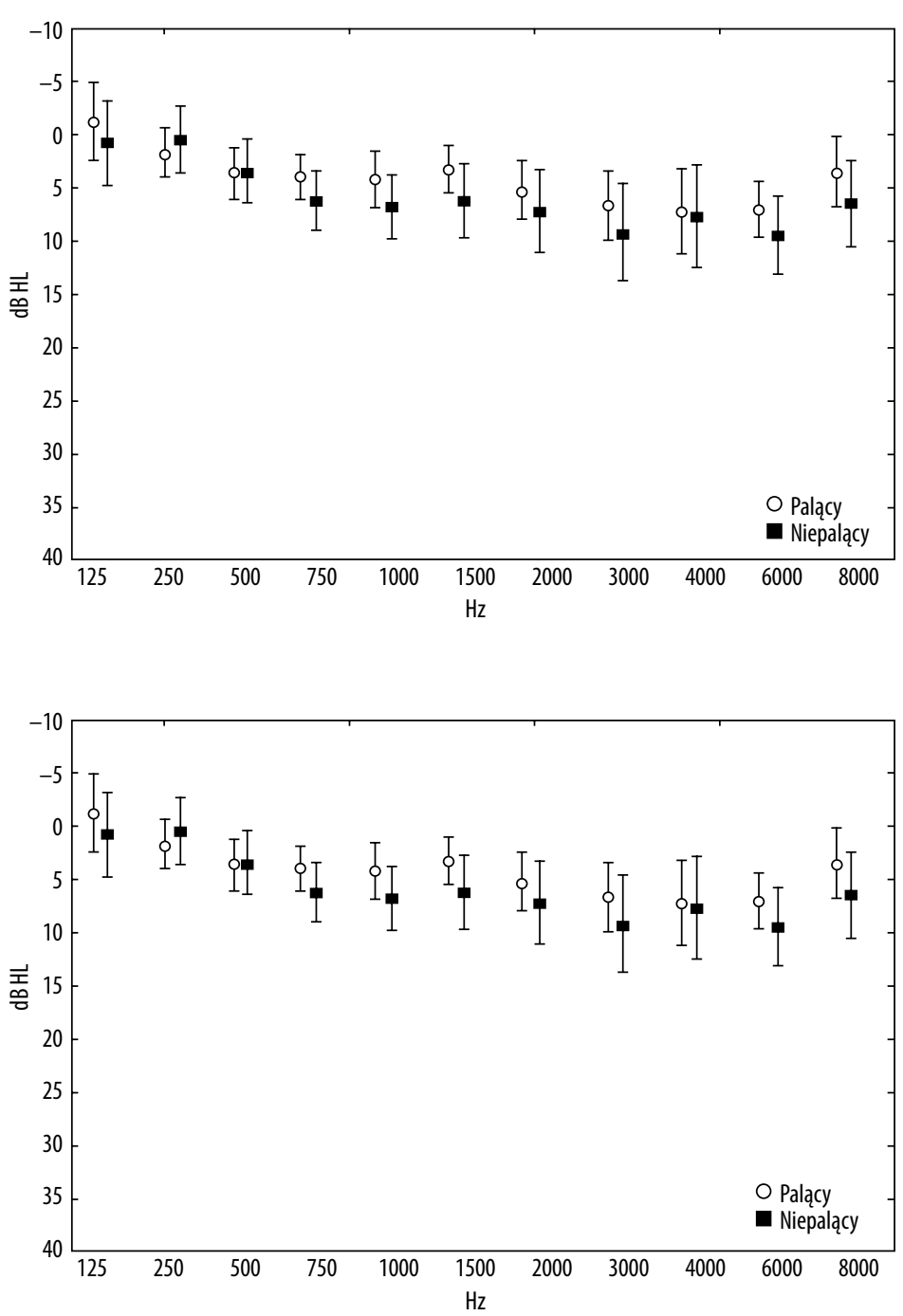

Rycina 1. Średnie progi styszenia $w$ audiometrii tonalnej dla ucha lewego $w$ grupie osób palących i niepalących (przedstawione rozrzuty wartości obrazują odchylenie standardowe)

Figure 1. Mean hearing threshold in pure tone audiometry for left ear in smoking and nonsmoking group (whiskers indicate standard deviation)

Rycina 2. Średnie progi styszenia w audiometrii tonalnej dla ucha prawego w grupie osób palących i niepalących (przedstawione rozrzuty wartości obrazują odchylenie standardowe)

Figure 2. Mean hearing threshold in pure tone audiometry for right ear in smoking and nonsmoking group (whiskers indicate standard deviation) wynika, że u osób dorosłych palenie papierosów w sposób istotny wpływa na obniżenie poziomów TEOAE. W badaniach Vinaya [18] odnotowano istotną statystycznie różnicę pomiędzy wynikami emisji otoakustycznych u osób palących i niepalących w każdej z badanych grup wiekowych. Osoby palące miały istotnie niższe średnie poziomy w porównaniu $\mathrm{z}$ niepalącymi.

Podobnie w badaniach Paschoal i Azevedo [17] wykazano negatywny wpływ palenia papierosów na wyniki emisji otoakustycznych. Istotne statystycznie różnice zaobserwowano zarówno dla ucha prawego, jak i lewego. Osoby palące miały niższe średnie poziomy emisji otoakustycznych $\mathrm{w}$ porównaniu $\mathrm{z}$ niepalącymi $\mathrm{w}$ uchu prawym dla częstotliwości $1 \mathrm{kHz}$. Natomiast w uchu lewym różnica ta występowała dla częstotliwości $1 \mathrm{kHz}$ oraz $4 \mathrm{kHz}$.

Rozbieżność wyników uzyskanych w niniejszych badaniach z pracami $[17,18]$ (brak istotnego obniżenia poziomów i SNR dla TEOAE) może być spowodowana mniejszą liczbą wypalanych papierosów i krótszym czasem narażenia na działanie nikotyny.

Należy zaznaczyć, iż w literaturze światowej obok doniesień mówiących o negatywnym oddziaływaniu palenia tytoniu na poziom emisji otoakustycznych istnieją również prace, $\mathrm{z}$ których wynika, że palenie tytoniu nie wpływa na występowanie uszkodzeń słuchu. Badania próbujące powiązać incydenty utraty słuchu z utrzymującym się poziomem kotyniny, substancji będącej metabolitem nikotyny, we krwi przeprowadzili Nondahl i wsp. [21]. Badania te nie potwierdziły istnienia żadnych istotnych statystycznie zależności pomiędzy tymi zmiennymi.

Wyniki niniejszej pracy w pewien sposób odbiegają od wyników większości przytoczonych powyżej prac dotyczących wpływu palenia na poziom emisji otoakustycznych. $\mathrm{Na}$ brak uwidocznienia efektu zmniejszenia poziomu emisji u osób palących mogło wpłynąć wiele czynników. Jednym $\mathrm{z}$ nich mogła być mała grupa badawcza, licząca 20 osób palących. Nie bez znaczenia może być również fakt, że ocenie poddawano ludzi młodych, w wieku do 19 do 30 lat, palących stosunkowo krótko i zazwyczaj niewielkie ilości papierosów dziennie. W związku z tym negatywne zmiany w organizmie, jakie wywołuje palenie tytoniu, mogły się jeszcze nie w pełni uwidocznić. Mogłoby to w pewien sposób wyjaśniać, dlaczego nie zaobserwowano większych różnic w wynikach emisji otoakustycznych w przypadku osób palących i niepalących dla badanych częstotliwości. Dodatkowo w ankiecie, którą wypełniali uczestnicy badań, 

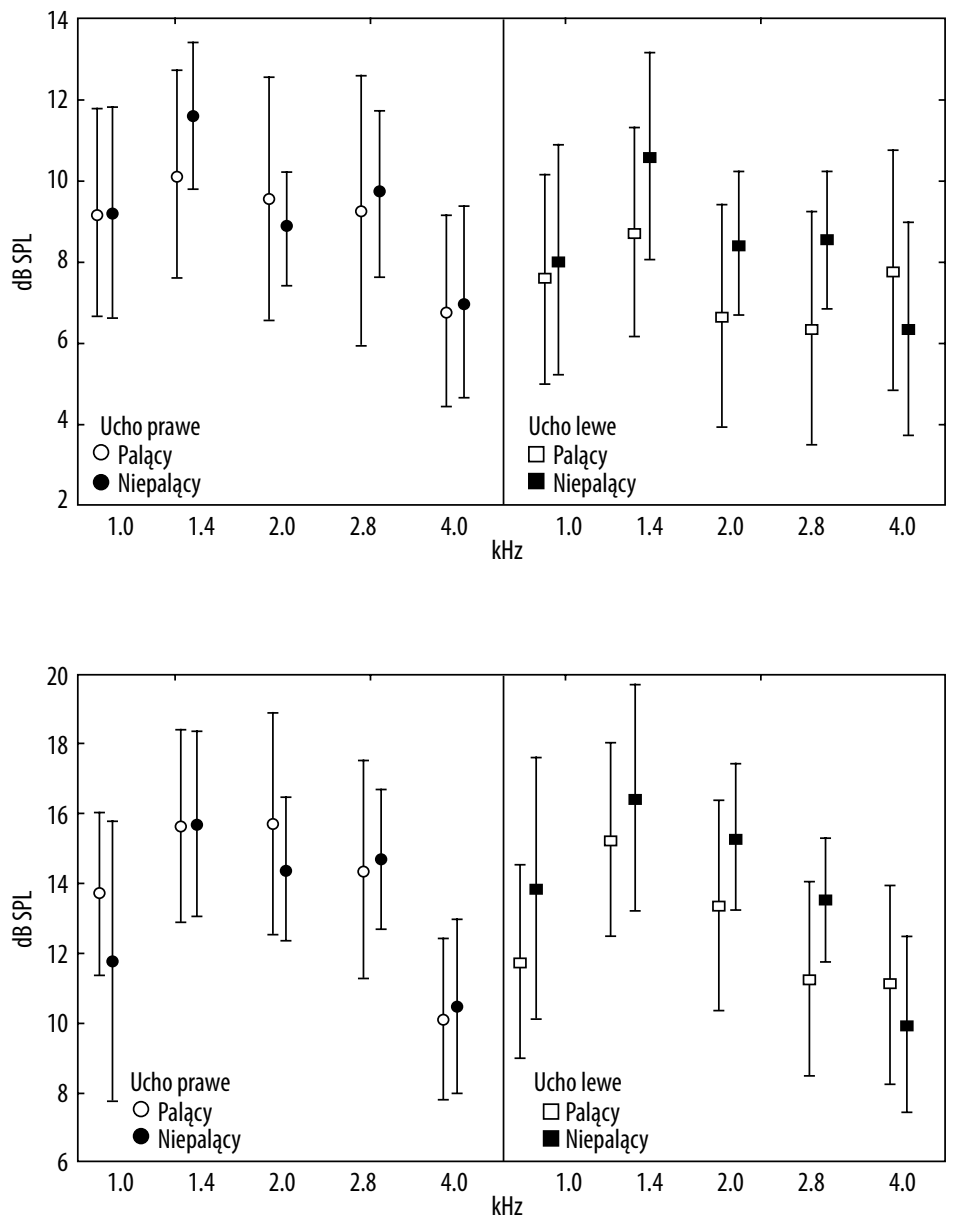

Rycina 3. Średnie poziomy odpowiedzi TEOAE dla ucha prawego i lewego w grupie osób palących i niepalących (przedstawione rozrzuty wartości obrazują odchylenie standardowe)

Figure 3. Mean TEOAE response level for right and left ear in smoking and nonsmoking persons (spread ratios show standard deviation)

Rycina 4. Średni SNR dla ucha prawego i lewego w grupie osób palących i niepalących (przedstawione rozrzuty wartości obrazują odchylenie standardowe)

Figure 4. Mean SNR for right and left ear in smoking and non smoking persons (spread ratios show standard deviation) zamieszczono jedynie pytania dotyczące leków hormonalnych przyjmowanych przez kobiety, jednak nie uwzględniono wahań hormonalnych związanych z cyklem menstruacyjnym, co mogło być istotnym czynnikiem wpływającym na poziom emisji otoakustycznych w grupie kobiet. Wzrost poziomu estrogenów może bowiem znacznie wpływać na wzrost poziomu emisji otoakustycznych wywołanych trzaskiem oraz emisji spontanicznych $[22,23]$.

W literaturze światowej brak jest badań bezpośrednio oceniających wpływ palenia tytoniu na emisje otoakustyczne $\mathrm{z}$ uwzględnieniem podziału na płeć. Dlatego też zagadnienie wpływu palenia papierosów na wyniki emisji otoakustycznych u kobiet i mężczyzn powinno stać się w przyszłości przedmiotem innych badań, które umożliwiłyby poszerzenie wiedzy $\mathrm{z}$ tego zakresu.

\section{Wnioski}

Podsumowując, w przypadku osób młodych, z prawidłowym słuchem, palących stosunkowo krótko jest prawdopodobnie jeszcze za wcześnie na zaobserwowanie istotnych zmian w TEOAE.

\section{Piśmiennictwo:}

1. Wilson LM i wps. Impact of tabaco control interventions on smoking initiation, cessation and prevelance: a systematic review. J Environ Public Health, 2012; 1-36.

2. "U.S. Departament of Health and Human Services: Preventing Tabacco Use Among Youth and Young Adults - A Report of the Surgeon General - Executive Summary", 2012, 33.

3. Ambrose JA, Barua RS. The pathophysiology of cigarette smoking and cardiovascular disease. J Am Coll Cardiol, 2004; 43: 1731-8.

4. Barcelaux DG. Medical toxicology of drug abuse: synthesis chemical and psychoactive plants. John Wiley \& Sons, 2012; 972.
5. Lutz WD, Weber LWD, Pierce JT. Toxicology of sensory organs, W: Luttrell WE, Jederberg WW, Still KR, red. Toxicology principles for the industrial hygienist. AIHA, 2008; 71-80.

6. Koop CE. Health consequences of smoking cardiovascular disease: Report of the surgeon general. DIANE Publishing, 2004; 203-40.

7. Rawool V. Introduction to ototoxins and hearing conservation. W: Hearing conservation: Occupational, recreational, educational and home settings. Thieme, 2011.

8. Fechter LD, Thorne PR, Nuttall AL. Effects of carbon monoxide on cochlear electrophysiology and blood flow. Hear Res, 1987; 27: 37-45. 
9. Kemp DT. Stimulated acoustic emissions from within the human auditory system. J Acoust Soc Am, 1978; 64: 1386-91.

10. Prieve BA. Otoacoustic emissions in infants and children. W: Madell JR, Flexer CA, red. Pediatric Audiology: diagnosis, technology and management. Thieme, 2008; 123-34.

11. Kemp DT. Otoacoustic emissions, their origin in cochlear function, and use. Br Med Bull, 2002; 63: 223-41.

12. Jędrzejczak WW, Kochanek K, Trzaskowski B, Pilka E, Skarżyński PH, Skarżyński H. Tone-burst and click-evoked otoacoustic emissions in subjects with hearing loss above 0.25 , 0.5, and $1 \mathrm{kHz}$. Ear Hear, 2012; 33(6): 757-67.

13. Śliwińska-Kowalska M, Kotyło P, Morawski K. Emisje otoakustyczne. W: Śliwińska-Kowalska M, red. Audiologia kliniczna. Łódź: Mediton; 2005, 149-62.

14. Fabry DA, Davila EP, Arheart KL, Serdar B, Dietz NA, Bandiera FC, Lee DJ. Secondhand smoke exposure and risk of hearing loss. Tob Control, 2011; 20: 82-5.

15. Cuickhanks KJ, Klein R, Klein BEK, Wiley TL, Nondahl DM, Tweed TS. Cigarette smoking and hearing loss - the epidemiology of hearing loss study. J Am Med Assoc, 1998; 279, 1715-9.

16. Sharbi Y, Reshef-Haran I, Burstein M, Eldad A. Cigarette smoking and hearing loss: Lessons from the young adult periodic examinations in Israel (YAPEIS). Isr Med Assoc J, 2002; 4: 1118-20.
17. Paschoal CP, Azevedo MF. Cigarette smoking as risk factor for auditory problems. Braz J Otorhinolaryngol., 2009; 75(6): 893-902.

18. Vinay. Effect smoking on transient evoked otoacustic emission and contralateral supression. Auris Nasalus Larynx, 2010; 37: 299-302.

19. Korres S, Pucci B, Gudayol N, Massa B, Gameiro M, Lopes C. Influence of smoking on developing Cochlea does smoking during pregnancy affect the amplitudes of transient evoked otoacustic emissions in newborns? Int J Pediatr Otorhinolaryngol, 2007; 71: 781-6.

20. Durante AS, Ibidi SM, Lotufo JP, Caravallo RM. Maternal smoking during pregnancy: Impact on otoacoustic emissions in neonates. Int J Pediatr Otorhinolaryngol, 2011; 75: 1093-8.

21. Nodhal DM, Cruickshans KJ, Dalton DS, Schubert CR, Klein BEK, Klein R. Serum cotinine level and incident hearing loss. Arch Otolaryngol Head and Neck Surg, 2004; 130: 1260-4.

22. Bell A. Circadian and menstrual rhythms in frequency variations of spontaneous otoacoustic emissions from human ears. Hear Res, 1992; 58(1): 91-100.

23. Al-Mana D, Ceranic B, Dajkanbach O, Luxon M. Alteration in auditory function the ovarian cycle. Hear Res, 2010; 268(1-2): 114-22. 